\title{
A Study on the Lack of Junior Middle School English Teachers’ Language Awareness
}

\author{
CUI Xiang, JIN Ming-hao (Corresponding Author) \\ Yanbian University, Yanji, Jilin Province, China
}

\begin{abstract}
This paper aims to take 20 Haikou XX Middle School English teachers as research subjects to investigate their language awareness by a questionnaire. According to the data, it can be seen that they seldom apply linguistic knowledge in classroom teaching. Their phonetic appearances are poor and pay too much attention to grammar teaching. Also, they rarely teach social cultural knowledge during teaching. And they still have a teacher-centered teaching concept. In case of enhancing their language awareness, teachers should change the tendency of paying too much attention to grammar and vocabulary knowledge, prevent the tendency of excessive emphasis on imitation, and advocate the learning model which combines language knowledge teaching and skills training. What's more, teachers should cultivate students' cultural awareness and combine language and culture in teaching English. Finally, teachers should establish a student-centered teaching concept, and help students develop positive emotions to learn English.
\end{abstract}

Keywords: English teachers, language awareness, student-centered teaching

\section{Introduction}

With the rapid development of second language acquisition, cognitive psychology, and other new subjects, the perspective of foreign teaching study has been changed a lot. Its focus is gradually shifting from exploring the best teaching method to learners' learning process and result, the internal and external factors that affect their study. In this transform process, a qualified teacher not only required adequate academic knowledge but also communicative language ability. Thus, it's very important for English teachers to improve their language awareness.

The biggest problem for Chinese to learn English is the lack of the target language environment. Classroom teaching is the main place for students to learn and use language. However, there are some main problems existing in classroom English teaching. This paper is going to demonstrate how to solve these problems by cultivating teachers' language awareness. If an English teacher does not have great language awareness, he/she is more likely to pay attention to grammar teaching only, which is very mechanical for English teaching. For English teachers with good language awareness, there are two basic points needed to be permeated in class. One is the structure of teaches' language awareness; the other is the using of teachers' language awareness. In the end, some flexible suggestions are given to cultivate teachers’ language awareness.

CUI Xiang, undergraduate student, Department of Law, Yanbian University, Yanji, China.

JIN Ming-hao, Ph.D., Associate Professor, Department of English, Yanbian University, Yanji, China. 


\section{Theoretical Background}

\section{Definition of Language Awareness}

Language awareness is an important concept for the explanation of psychological phenomena. It emerges as a movement in the UK at the beginning of the 1970s, founded by Hawkins (1970), mainly as a reaction to dominant theories about language learning based on behaviorist principles of habit formation.

Language awareness includes language knowledge consciousness, learning strategy consciousness, teaching method consciousness, learning demand consciousness, and pragmatic consciousness in intercultural communication. Generally speaking, language awareness is about the language system itself.

\section{The Content of Language Awareness Teaching}

Language awareness teaching aims to provide learners with the ability to gain insight into the nature of language. As an educational goal, it emphasizes learners' ability to deal with the barriers while using language in order to reach a higher level of understanding and use of language.

Language awareness teaching reflects the student-centered teaching philosophy. It emphasizes the active participation of students and develop their potentials to discover and solve problems. From primary school, to train and gradually improve students' language awareness is not only helpful to promote long-term stable development of their language skills, but also contribute to build their cognitive ability and overall quality. Thus, English teachers should not only have English language expressions, but also a strong sense of language awareness teaching ideas.

\section{Empirical Studies on Language Awareness}

The role of language awareness in second language (L2) learning is widely discussed. The journal, Language Awareness, is influential in promoting discussion of this issue. In current cognitive psychology, the mainstream point of view is that it is impossible to learn an L2 without langauge awareness.

James (1996) defined language awareness as the possession of metacognitions about language in general, some bit of language, or a particular language over which one already has skilled control and a coherent set of intuitions.

Carter (2003) defined language awareness as the development in foreign language learners of an enhanced consciousness and sensitivity to the forms and functions of language. In general, language awareness is the awareness of linguistic factors governing language use, organizing and analyzing one's internalized language, and evaluating of language learning experience, or the knowledge about language.

Andrews (2007), on the other hand, proposed that foreign language teachers with good language awareness can adjust their verbal expressions according to students’ actual level, teach them new language knowledge, and promote their language skills by using appropriate language medium. To a great extent, teachers’ language awareness means the close relationship between teachers' language knowledge and the ability of using a language. And also it is the link between the language level of foreign language teachers and the subject pedagogical knowledge. It is the language knowledge and skills after teaching reflection.

Wei (2011), based on the theory of teachers' language awareness, founded the level of English teachers’ language awareness is poor and teachers are also lack of English meta-language knowledge, teaching reflection, and self-consciousness by means for meta-language awareness test and interview for middle school English teachers. 
He and Gong (2013) explored the difference, stages, and regularity of the development of language awareness in the process of foreign language learning from the perspective of pragmatics and grammatical awareness. The results showed that there is a significant difference in the development of pragmatics and grammatical consciousness in different learning stages and different language levels. The learner's grammatical consciousness development precedes pragmatic consciousness, and the learner's pragmatic consciousness rises linearly. Grammatical consciousness is showing the development characteristics from low to high and then gradually reduced.

Up till now, the research has been carried out mainly on the definition and essence of the language awareness so that more empirical studies are needed to analyze English teachers language awareness in teaching English.

\section{Research Design}

\section{Research Questions}

There are three research questions in this study. They are:

1. Do teachers apply linguistic knowledge in classroom teaching?

2. Do teachers explain specific details when texts are involved social cultural knowledge?

3. Do teachers have a student-centered teaching concept?

\section{Participants}

The participants of this study are 20 teachers from Haikou XX Junior Middle School, which is a normal rural middle school in Haikou City, Hainan Province.

\section{Instrument}

A self-made questionnaire was used to collect the data and take Haikou XX Junior Middle School as the research subject. There are three parts in the questionnaire, including questions reflected with linguistic knowledge, social and cultural knowledge, and teaching concept.

\section{Data Collection}

20 questionnaires were given out. Finally, 20 valid questionnaires were taken back. SPSS 12.0 was used to collect and analyze the data.

\section{Result and Discussion}

According to the questionnaire survey, it is not difficult to see the situation of Junior Middle School English teachers' language awareness is not optimistic, shown in the following part.

\section{Linguistic Knowledge}

In this part, nine questions are designed to investigate teachers' linguistic knowledge. Linguistics and foreign language teaching have a close relationship to each other. Linguistics provides guidance to foreign language teaching. On the other hand, language teaching practice enhances linguistic theories. In foreign language teaching, teachers should apply linguistic knowledge appropriately to let students learn English more systematically. Taking all the above into consideration, linguistic knowledge has a close connection with foreign language teaching. If teachers want their students to acquire the knowledge more effectively in the process of 
language teaching, teachers should use proper linguistic knowledge and methodologies to teach students more successfully. In order to investigate English teachers' linguistic knowledge in terms of phonetic and grammar, five questions are designed, as shown in Table 1.

Table 1

Phonetic and Grammar

\begin{tabular}{llll}
\hline Questions & Agree & Neutral & Disagree \\
\hline Will you pay more attention to intonation when you read text? & $4(20 \%)$ & $6(30 \%)$ & $10(50 \%)$ \\
It’s necessary for you to improve your quality of phoneme. & $13(65 \%)$ & $4(20 \%)$ & $3(15 \%)$ \\
It’s important to teach grammar knowledge. & $11(55 \%)$ & $5(25 \%)$ & $4(20 \%)$ \\
You will use a whole class to explain the grammar system. & $15(75 \%)$ & $3(15 \%)$ & $2(10 \%)$ \\
I think that teaching language knowledge is conducive to the & $5(25 \%)$ & $3(15 \%)$ & $12(60 \%)$ \\
improvement of English teaching quality. & & \\
\hline
\end{tabular}

Shown in Table 1 , among 20 teachers, $50 \%$ teachers $(\mathrm{N}=10)$ do not pay attention to intonation when reading text. $65 \%(\mathrm{~N}=13)$ teachers thought it's necessary to improve their phonetic appearance. In terms of grammar, $55 \%(\mathrm{~N}=11)$ teachers thought teaching grammar is very important. Even more, $75 \%(\mathrm{~N}=15)$ will use a whole class to explain the grammar system. $60 \%(\mathrm{~N}=12)$ teachers thought that teaching language knowledge is conductive to improve English teaching quality. This shows that teachers tend to teach grammar knowledge while teaching English.

Only one question is designed to investigate intonation, as shown in Table 2.

Table 2

Intonation

\begin{tabular}{lll}
\hline Question & Rising tone & Down tone \\
\hline What is the intonation of “It’s a lovely day, isn't it?”? & $15(75 \%)$ & $5(25 \%)$ \\
\hline
\end{tabular}

Table 2 shows that $75 \%(\mathrm{~N}=15)$ teachers thought that the intonation of this sentence “It's a lovely day, isn't it?” should be raised up.

There are 2 questions are designed to investigate teachers' linguistic and phonetic knowledge, as shown in Table 3.

Table 3

Linguistic and Phonetic Knowledge

\begin{tabular}{lll}
\hline Question & Yes & No \\
\hline Have you ever received a system training of linguistics? & $3(15 \%)$ & $17(85 \%)$ \\
Have you ever received a system training of phonetic knowledge? & $4(20 \%)$ & $16(80 \%)$ \\
\hline
\end{tabular}

Tables 3 shows $85 \%(\mathrm{~N}=17)$ teachers have not learned the linguistic knowledge systematically. $80 \%(\mathrm{~N}=$ 16) teachers said they never received a systematic training of phonetic knowledge.

One question is designed to investigate teachers' linguistic knowledge, as shown in Table 4. 
Table 4

Linguistic Knowledge

\begin{tabular}{lllll}
\hline Question & Yes, with consciously & Maybe & No special attention & Not at all \\
\hline $\begin{array}{l}\text { Have you ever applied linguistic theory } \\
\text { to everyday English teaching? }\end{array}$ & $1(5 \%)$ & $5(25 \%)$ & $8(40 \%)$ & $6(30 \%)$ \\
\hline
\end{tabular}

From Table 4, it can be seen that $40 \%(\mathrm{~N}=8)$ teachers did not pay special attention to whether they ever applied linguistic theory to everyday English teaching. 30\% ( $\mathrm{N}=6)$ teachers said they never applied linguistic theory to everyday English teaching. Only 5\% ( $=1)$ teacher applied linguistic theory to English consciously teaching and $25 \%(\mathrm{~N}=5)$ teachers said they should have had but did not realize.

It can be seen that most of the teachers have confused understanding about phonetic rules so that their phonetic knowledge is very limited.

\section{Social and Cultural Knowledge}

Five questions on social and cultural background knowledge are designed to investigate its application in English teaching, which can help to learn authentic English, and also teach idiomatic English to students, as shown in Table 5.

Table 5

Inquiry

You met a foreigner for the first time, and you wanted to know his or her name. What would you like to say?

What's your name? May I have your name? My name is... Would you mind telling me your name?

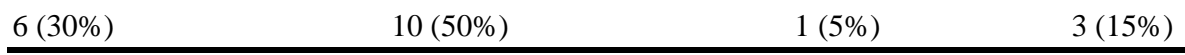

Table 5 shows that teachers' ability to choose different communication strategies is weak. In daily communication, when we ask people's name, we generally use expression like "May I have your name?” or “Would you mind telling me your name?”. So $45 \%(\mathrm{~N}=9)$ teachers choose A and D. But there is only one teacher who chose C. It indicates that some teachers do not know the sentence structure "My name is ..." can also be used to ask people's name.

One question is designed to investigate different animal meaning between western and China cultural, as shown in Table 6.

Table 6

Animal Meaning

\begin{tabular}{lllll}
\hline Question & Peacock & Dragon & Owl & Dog \\
\hline $\begin{array}{l}\text { Which of the following animal(s) has (have) negative meaning(s) } \\
\text { in western culture? }\end{array}$ & $3(15 \%)$ & $2(10 \%)$ & $7(35 \%)$ & $8(40 \%)$ \\
\hline
\end{tabular}

In western culture, the symbolic meanings of peacock, dragon, owl, and dog are completely different from those meaning in China. In Chinese culture, peacock has a auspicious and beautiful meaning. While in western culture, it has the meaning of being proud of something. There is a saying that is "as proud as a peacock". In Chinese culture, the dragon represents the rich, sacred, and status. In western culture, the dragon is often used to refer to evil, brutal, and cunning man. In western culture, the owl is the wisdom of the bird, like idiom "as wise as an owl”. In western culture, unlike Chinese culture, dog does not have derogatory color, and the words associated 
with it are complimented. In Table 6, due to the lack of understanding of those culture differences and influenced by the cultural additions of these animals, 35\% $(\mathrm{N}=7)$ teachers and $40 \%(\mathrm{~N}=8)$ teachers chose owl and dog.

Two questions are designed to investigate teachers' social cultural knowledge, as shown in Table 7.

Table 7

Social and Cultural Knowledge

\begin{tabular}{llll}
\hline Questions & Agree & Neutral & Disagree \\
\hline $\begin{array}{l}\text { I like to read some foreign news, magazines, etc., and understand the } \\
\text { various English-speaking countries' customs. }\end{array}$ & $4(20 \%)$ & $3(15 \%)$ & $13(65 \%)$ \\
In class, I will explain in detail when the text is related to cultural knowledge. & $3(15 \%)$ & $2(10 \%)$ & $15(75 \%)$ \\
\hline
\end{tabular}

From Table 7, it can be seen that only $20 \%(\mathrm{~N}=4)$ teachers said they like to read some foreign news, magazines, etc., and understand the various English-speaking countries' customs. Meanwhile, $15 \%(\mathrm{~N}=3)$ teachers will explain in detail when the text involved and cultural knowledge during teaching.

\section{Teaching Concept}

Five questions were designed to investigate teachers’ teaching concept, as shown in Table 8.

Table 8

Teaching Concept

\begin{tabular}{|c|c|c|}
\hline Question & Yes & No \\
\hline I think that most of the teaching time in class should be explained by teachers only. & $12(60 \%)$ & $8(40 \%)$ \\
\hline $\begin{array}{l}\text { English teaching should be teacher-centered and should be adjusted according to the specific situation of } \\
\text { students. }\end{array}$ & $15(75 \%)$ & $5(25 \%)$ \\
\hline I think English teaching should be a kind of activity to develop students' communicative competence. & $6(30 \%)$ & $14(70 \%)$ \\
\hline $\begin{array}{l}\text { I think the key to learn English well is to practice listening and speaking again and again in order to } \\
\text { achieve good results. }\end{array}$ & $11(55 \%)$ & $9(45 \%)$ \\
\hline
\end{tabular}

From Table 8 it can be found that $60 \%(\mathrm{~N}=12)$ teachers thought most of the teaching time in class should be explained by teachers only and what the students need to do is to listen, imitate, and practice. $75 \%(\mathrm{~N}=15)$ teachers thought English teaching should be teacher-centered and should be adjusted according to the specific situation of students. It proves audio-lingual teaching method is widely used in classroom teaching.

$75 \%(\mathrm{~N}=15)$ teachers thought that English teaching should be teacher-centered and adjusted according to the specific situation of students. There are also $25 \%(\mathrm{~N}=5)$ teachers who thought that the classroom teaching should be student-centered.

\section{Suggestions}

\section{Suggestions on Linguistic Knowledge Teaching}

Change the tendency of paying too much attention to grammar and vocabulary knowledge. The ability of comprehensive use of language is cultivated in language practice. In the process of learning English, English should be learned by listening, speaking, reading, and writing. For this reason, language knowledge study should be based on language practice. Teachers can use some ways to teach English such as tips, attention and observation, discovery, analysis, induction, comparison, summary, etc. At the same time, it is necessary to organize students to participate in the above process consciously. Teachers should provide meaningful sentences or passages so that students can learn the meaning and usage of words, grammar points, and fluent natural voice 
and intonation so as to help students master the practical language knowledge.

Prevent wrong tendency. It is a wrong tendency to put emphasis on imitation rote learning and mechanical training during English teaching. English teaching should not be paid too much emphasis to rote learning and mechanical training. On the contrary, teachers should pay attention to design teaching process scientifically. They should create a flexible and funny way so that students can learn English efficiently. And then, students can use linguistic knowledge during listening, speaking, reading, and writing in language communication practice. Students can also turn linguistic knowledge into the tool of English communication.

Advocate learning model. Teachers should advocate the combination of linguistic knowledge teaching and skills training. Linguistic knowledge is not only made up of phonetic, words, and grammar rules, but also conceptual meaning, language chapter structure, cultural difference, and people' relationship and so on. Base on the development of students' language skill, linguistic knowledge, emotional attitude, learning strategy, and culture awareness, English courses in elementary education stage should cultivate students' comprehensive language application ability. For this reason, linguistic knowledge teaching and skills training must mobilize students' initiative, accumulation, and inquiry, etc.

\section{Suggestions on Social Cultural Knowledge}

Cultivate students' cultural awareness. The cultural elements in discourses are ubiquitous in the textbook. In the teaching process, teachers should find and effectively use variety of cultural information in the textbook, and help students improve their cultural awareness by making them understand cultural composition, various forms of cultural context, and potential cultural factors in the discourses. What's more, students' knowledge of language and culture can be consolidated and improved through practice. Teachers should strive to provide students with a suitable language environment so that students have more opportunities to do practical communication. For example, teachers can organize students to participate in a variety of English activities in real situation.

Combine language with culture teaching. English teachers should coordinate the relationship between teachers, students, teaching materials, and teaching environment. What's more, teachers should mobilize students' enthusiasm and initiative through a variety of methods and channels. Also teachers should help students establish a clear cultural awareness and improve their intercultural communicative competence. At the same time, students can learn language knowledge and improve their ability to use language. Teachers should optimize the teaching mode to achieve the organic combination of language and culture teaching. In this process, it's important to use teaching materials in cultural information. It is not only an important element which can be used to cultivate students' cultural awareness, but also can help teachers optimize teaching plan and adjust teaching method. In a word, teachers should make the language teaching and culture teaching as a whole. In English teaching, they should pay attention to cultivate students' cultural awareness and intercultural communicative competence. In order to achieve better teaching effect, teachers should apply advanced teaching methods.

\section{Suggestions on Teaching Concept}

Help students develop positive emotions. First, teachers should be concerned and respect students, finding out students' flash point. Secondly, teachers should develop students' positive feelings to internalize the awareness of teaching process and teaching behavior. Teachers should be good at dealing with teaching materials 
and using a variety of teaching methods to enable students to enjoy learning. Teachers also need to be good at using more encouragement language. Finally, teachers should teach students according to their characteristics. In a word, teachers should help students develop their interest and motivation of learning English and help them build their self-esteem and self-confidence.

Help students improve the ability to understand and control their emotions. Negative factor is an important reason for the failure of English learning. Teachers should observe and analyze the reasons why students fail to learn English in daily English teaching and actively counsel with students and try to reduce students' learning anxiety. What's more, teachers should teach students to be fully affirmed their progress and success so as to improve their confidence. When facing to failure, students should calm down to analyze the reason and reflection, learn self-regulation and then reduce anxiety. At the same time, teachers should have a plan to guide students to absorb experience so that they can control their learning strategy and behavior. In this way, students can improve the ability of self-awareness and self-confidence during the process of self-education. Students also can learn to better control their emotions and then develop a better mental quality.

\section{Conclusion}

With the development of English teaching methods, English teachers play a very important role in English learning. At the same time, English teachers’ language awareness is a significant factor during English teaching. This paper designed a questionnaire survey in order to investigate teachers' understanding about linguistic knowledge, social cultural concept, and teaching concept. According to the data, the major findings are: They seldom apply linguistic knowledge in classroom teaching. Their phonetic appearances are poor and they pay too much attention to grammar teaching. Also, they rarely teach social cultural knowledge in class. Their teaching model is still teacher-centered and so on.

In that case, teachers should change the tendency of paying too much attention to grammar and vocabulary knowledge, prevent the tendency of excessive emphasis on imitation, rote learning, mechanical training, and advocate the learning model which combines language knowledge teaching and skill training. What's more, teachers should cultivate students' cultural awareness through combining language with culture in English teaching. Last not the least, teachers should establish a student-centered teaching concept, help students develop positive emotions and create a pleasant learning atmosphere, eliminate negative emotions, and improve the ability to understand and control their emotions.

To sum up, teachers from junior middle school should make some efforts on the cultivation of language awareness so that they can improve their English teaching skills and learn proper English as well.

\section{References}

Andrews, S. (2007). Teacher language awareness. Cambridge: Cambridge University Press.

Carter, R. (2003). Language awareness. Foreign Language Teaching \& Research in Basic Education, (5), 42-44.

Hawkins, E. (1999). Foreign language study and language awareness. Language Awareness, 8(3), 124-142.

He, Z. C., \& Gong, Y. Z. (2013). An empirital study on language awareness of Chinese English learners: From the perspectives of PA and GA. Modern Foreign Languages (Quarterly), 26(3), 278-285.

James, C. (1996). A cross-linguistic approach to language awareness. Language Awwaress, 5(3-4), 138-148.

Wei, R. (2011). A rethink about ideal English teachers: An empirical study based on second langauge teachers' language awareness. Journal of Southwest Agricultural University (Social Science Edition), 9(8), 107-111. 